\title{
Temporary Disfigurement
}

Bless temporary disfigurement

for it begins and ends.

One combs the hills

to collect the severed parts.

He sews so awkwardly it seems there cannot

be brilliance and perfection

but they are in the very awkwardness,

and after all it is not centuries but afternoons

and the young man is whole again,

torn and repaired.

He stares at his arms

before he forgets them,

before he forgets the surgeon,

and he is ready for love after the terrible solitude, and for solitude, of course. 